DOI: 10.1515/ausp-2016-0040

\title{
Variants of Identity - Identity in Change
}

Erzsébet Dani: Identitásgyarmatosítás Erdélyben. Identitásdrámák és interkulturális stratégiák a Trianon utáni székelymagyar irodalomban [Colonization of Identity in Transylvania. Dramas of Identity and Intercultural Communication in SzékelyHungarian Literature after Trianon] Pro-Print Publishing House, Miercurea-Ciuc, 2016

\author{
Review by: Katalin LAJOS \\ Sapientia University \\ Faculty of Economics, Socio-Human Sciences and Engineering, Miercurea-Ciuc, \\ Department of Human Sciences \\ lajoskati@yahoo.com
}

Erzsébet Dani's volume represents an interesting approach to twelve novels written by eight Hungarian writers between the two world wars. It is interesting from more points of view.

First of all, the chosen novels have some common particularities: most of them are written by "Székely"-Hungarians who were born in the eastern part of Transylvania, a region which was detached from Hungary and attached to Romania according to the terms of the Treaty of Trianon following World War I, in 1920. The second similarity is the main topic of the chosen novels: how the characters can (or cannot) manage their identity in a new socio-political context, when a new state authority tries by all means to "integrate" them into a new national identity.

Secondly, it is an interesting study due to the interdisciplinary approach to the subject: it fructifies the terminology and the conclusions of a wide range of social sciences in the interpretation of the types of identities and the strategies of the characters to manage their identity. It uses the theoretical background of the assimilation theories, the theory of colonialism-postcolonialism, various theories of identity, the theories related to the study of cultural memory, communication, and intercultural communication. 
The book is structured into 20 chapters, the first chapter being a short introduction, with the last one containing a detailed bibliography. The rest of the chapters are structured in two distinct groups: chapters 2-6 treat the theoretical frame of the further discussions and the following chapters analyse twelve novels and sociographies from the interwar period, focusing on the issue of identity (Rózsa Ignácz’s Született Moldovában and Anyanyelve magyar, József Nyírő’s Az én népem, Néma küzdelem, and Uz Bence, Áron Tamási’s Ábel and Szülóföldem, György Bözödi’s A rög alatt, Elek Benedek’s Édes anyaföldem!, Dezső László’s A kisebbségi élet ajándékai, and Sándor Kacsó’s Vakvágányon).

The entire book is characterized by a concise style, which is the strength of this writing: the author sticks to the proposed theme and is aware of the reader's possible questions all the time, answering them even before these questions could arise in the reader's mind. It is clearly specified in the Introduction that the collection of primary and secondary literature data was closed on the $16^{\text {th }}$ of December 2013 and every theory, scientific term, or category is used only to the extent in which they can serve the analysis of the chosen works in the proposed context. The historical survey of the trauma of Trianon (Chapter 2), the short presentation of the history of the Székelys and the influence of this history on the Székely identity (Chapter 3), the national characterology of this ethnic group (Chapter 4), and the special attention paid to the situation of Hungarians in "inner" diaspora serve to understand better the political-historical-sociological environment, in which the writers and their characters are moving. These are important chapters mainly for those who are not familiar with this historical period and region. Chapter 6 offers a 38-page presentation of theoretical backgrounds used in literary interpretation. The author thinks that the theories of assimilation, their historical, demographical, and socio-psychological aspects are useful to the proposed analysis even though it is heavily charged ideologically. She mentions numerous authors related to this theoretical frame, presents several models which describe the phenomena of assimilation (e.g. M. Gordon's model, J. M. Yinger's model, B. B. Hess's model), and selects some useful notions such as the terms of ethnic group, ethnic minority and majority, cultural assimilation, dissimilation, acculturation, segregation, amalgamation, etc. In a similarly succinct way, the author makes a survey of the other theories mentioned by me in the third paragraph of this text and she specifies to what extent they can be used in the analyses of the chosen writings.

I will not make a detailed presentation of the following eleven chapters; however, I have to say that the order in which the previously mentioned writings are presented follows the types of identity from simple to complex, the reactions of the characters to the changed situation from univocal attitudes to problematic or ambiguous ones. Every chapter also lays emphasis on the existence or non-existence, capacity or incapacity of intercultural communication, 
which is seen as a warrant for preserving identity and surviving in a (mostly unfriendly) intercultural context. The types of identities are described by terms as "uncolonizable identity" in the case of the trilogy of Ábel and Uz Bence, "fragile balance of identity" and "climbing colonization of identity" (the case of Elek Benedek's and Áron Tamási’s autobiographical works), "the confronting management of identity" (in Sándor Kacsó's novel), "intercultural management of identity” (in Rózsa Ignácz's novels), "non-motivated collective identity" and “consciously assumed collective identity” (in József Nyírő’s novel Az én népem), or "deteriorating roots of identity" (in György Bözödi’s Romlás).

For all the characters presented in this survey, Trianon was also a personal drama beyond being a collective one; the after-war situation challenged their personal identity and forced them to find an appropriate response to this challenge. The various strategies used by them to present, reinforce, change, or hide identity are well-known for many (if not all) readers who belong to the Hungarian minority in the neighbouring countries of Hungary. Even though the author of the present book never makes any reference to actual political or cultural scenes, the Székely-Hungarian reader (as I am, for instance) cannot help but make a comparison to actual situations, when even in the new millennium we can experience similar situations. This fact shows, on the one hand, the actuality of the literature of these canonic writers and, on the other hand, it warns us of the fact that even today, almost a hundred years later, identity is a fragile entity in this part of the world.

In conclusion, I would say that the accuracy of this study legitimates the title, which at the first glance may appear too bold: colonization of identity. The Eastern European reader who is a member of a minority is not used to this kind of "hard terms". Maybe it is time to face the facts as they are, to name the facts by their "names", and an interdisciplinary study can offer the proper terminology to do that. I would recommend this volume to a wide range of specialists (literary historians, historians, anthropologists, and sociologists), but also to all those who are interested in an overview of the subject of identity in a certain historical context. 